\title{
Retrobulbar secondary plasmacytoma: a case report and systematic review of the literature
}

\author{
Mehrdad Payandeh ${ }^{1}$, Noorodin Karami ${ }^{2}$, Soode Enayati ${ }^{3}$, Afshin Karami ${ }^{4},{ }^{*}$, Mehrnoush Aeinfar $^{1}$, Fatemeh \\ Yari $^{5}$
}

${ }^{1}$ Department of Hematology and Medical Oncology, Kermanshah University of Medical Sciences, Kermanshah, Iran

${ }^{2}$ Department of Genetics, Shahid Sadoughi University of Medical Sciences, Yazd, Iran

${ }^{3}$ Department of Biotechnology, Science and Research Branch, Islamic Azad University, Tehran, Iran

${ }^{4}$ Department of Hematology, Shahid Beheshti University of Medical Sciences, Tehran, Iran

${ }^{5}$ Department of Nursing and Midwifery Imam Reza Hospital, Kermanshah University of Medical Sciences,

Kermanshah, Iran

Correspondence

Afshin Karami, Department of Hematology, Shahid Beheshti University of Medical Sciences, Tehran, Iran

Email: Afshinkarami72@gmail.com

History

- Received: 17 August 2018

- Accepted: 10 September 2018

- Published: 29 September 2018

DOI :

https://doi.org/10.15419/bmrat.v5i9.482

\section{Check for updates}

Copyright

(๑) Biomedpress. This is an openaccess article distributed under the terms of the Creative Commons Attribution 4.0 International license.

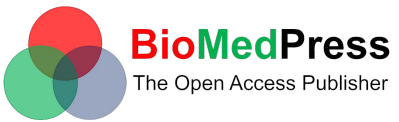

\begin{abstract}
Multiple myeloma is described by the proliferation of malignant plasma cells, in which orbital involvement is rare. In this report, we collected all cases with orbital multiple myeloma from 2009 to 2018 and investigated the characteristics such as sex, age, common orbital symptoms, unilateral or bilateral and different therapeutic options. Also, we reported an uncommon case of multiple myeloma that has been developed into plasmacytoma. Our patient had been initially diagnosed with multiple myeloma, but after a few months, the disease had progressed to secondary extramedullary plasmacytoma in the retrobulbar. Therapeutic measures, such as surgery to prevent its development in the patient's eye, were successful.
\end{abstract}

Key words: Extramedullary plasmacytoma, Multiple myeloma, Orbital involvement, Retrobulbar

\section{INTRODUCTION}

Multiple myeloma is a tumor of malignant plasma cells that consider as the second most common hematologic malignancy ${ }^{1}$. This disease has an age-adjusted incidence of 4.7 cases per 100,000 populations ${ }^{2}$. It often occurs in adults, and the mean age at diagnosis is 70 years $^{3}$. One of the most prominent features of this disorder is the presence of more than $10 \%$ clonal plasma cells in the bone marrow or biopsy associated with end-organ damage ${ }^{2}$. Also, in 1846, Dalrymple and Bence Jones discovered an uncommon plasma cell tumor known as plasmacytoma ${ }^{4}$. The etiology of plasmacytoma remains largely unknown, but factors such as viral pathogenesis have been identified and genetic factors may also be involved ${ }^{5}$. The purpose of this paper is to report a 62-year-old man with a clinical and pathological history of multiple myeloma, who presented evidence of a mass in the retrobulbar area of the eye.

\section{CASE PRESENTATION}

In January 2018, a 62-year-old man was referred to our Clinic of Hematology and oncology, with one week of back pain history, and loss of consciousness in the neurological examination. Further analysis revealed the symptom of kidney failure. In primary laboratory investigations, he had normocytic normochromic anemia with $\mathrm{Hb}: 9.6 \mathrm{~g} / \mathrm{dL}$, normal WBC and a decrease in platelet count (WBC: $8,300 / \mathrm{mm}^{3}$; Platelet count: $79,000 / \mathrm{mm}^{3}$ ). Also, renal function tests (RFT) and serum electrolytes were usually performed in multiple myeloma. The results of these tests showed hypergammaglobulinemia $(5 \mathrm{~g} / \mathrm{dL})$ and an increase in blood urea nitrogen (BUN) and serum creatinine (Cr) levels (BUN $64 \mathrm{mg} / \mathrm{dL}, \mathrm{Cr} 8.1 \mathrm{mg} / \mathrm{dL}$ ). Magnetic resonance imaging of the lumbar spine indicated vertebral collapse at T12 and L2. Examination of thebone marrow aspiration (BMA) and bone marrow biopsy revealed that a high percentage of plasma cells ( $>20 \%$ plasma cells) were negative for CD19, and positive for CD38, CD138 (Figure 1).

Our diagnosis was multiple myeloma and immediately started treatment with bortezomib, cyclophosphamide, and dexamethasone (the approved VCD is preferable as induction therapy for newly diagnosed multiple myeloma especially with renal failure). Also, zoledronic acid was used to reduce bone pain.

After 6 cycles, the initial response to treatment was relatively good. Five months later, the patient referred to an ophthalmologist with symptoms such as swelling of the right eyelid with ptosis, diplopia and blurred vision. In fundus examination, few scattered hemorrhages were seen in the left eye and the results of Visual Acuity for this eye were as follows: OD: $6 / 10$, OS: 4/10. Also, the results of orbit computed tomography (CT) demonstrated a soft tissue mass $(26 \times 12 \mathrm{~mm})$ in the retrobulbar of the left eye (Figure 2). In fine needle aspiration cytology (FNAC) of the mass, mature and immature plasma cells were observed, which led to the diagnosis of secondary extramedullary plasmacytoma. Thus, the patient underwent surgical debulking, the lesion was removed 


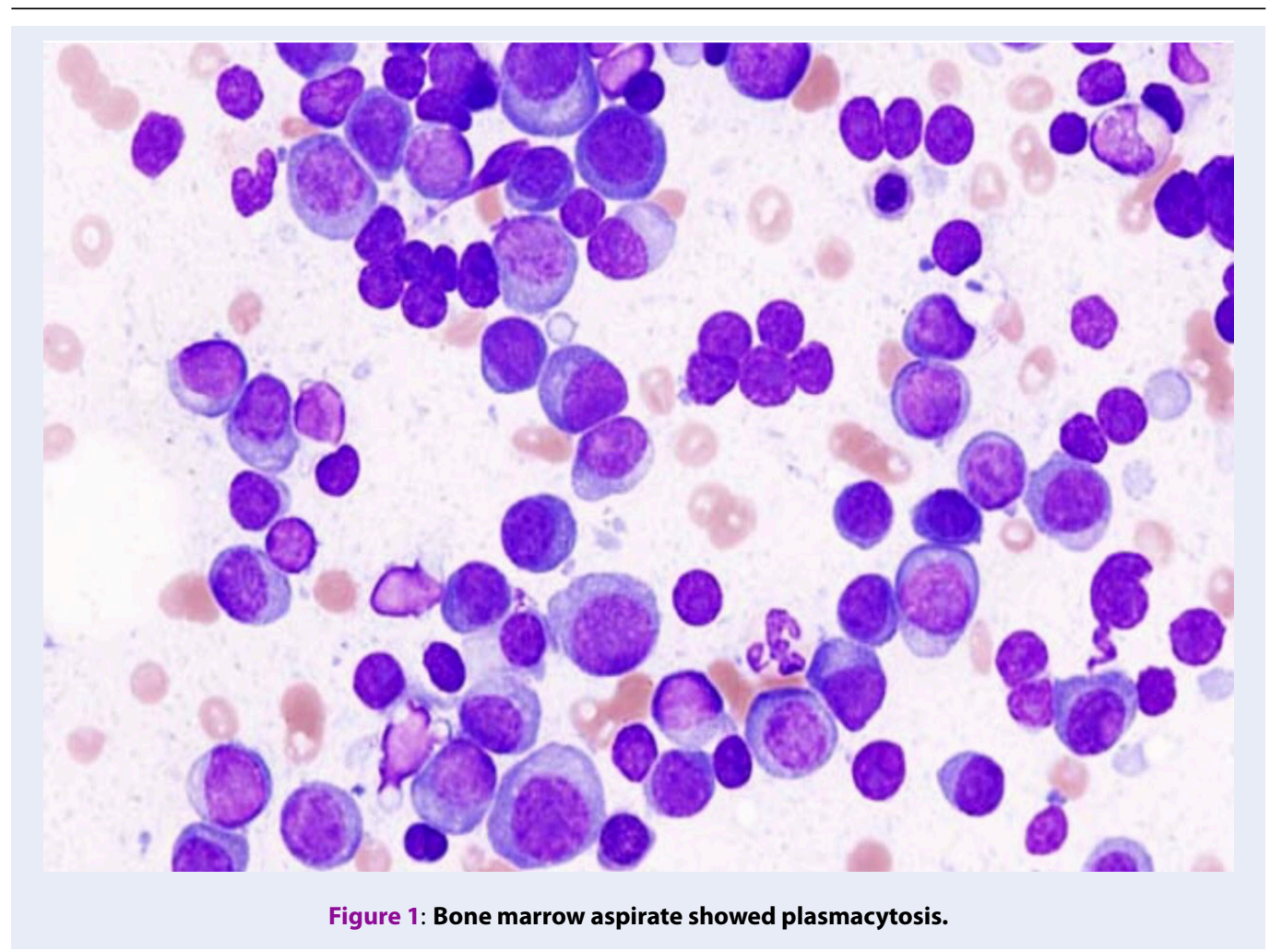

from the retrobulbar area and the result was successful. Currently, the patient's condition is good, and he is continuing chemotherapy cycles with bortezomib and dexamethasone.

\section{DISCUSSION}

Plasmacytoma, as an unusual tumor of malignant plasma cells, indicates $5-10 \%$ of all plasma cell neoplasms ${ }^{6}$ and plasmacytoma can occur as a primary or secondary tumor, based on the presence or absence of systemic disease ${ }^{7}$. Also, these neoplasms are divided into four different types: solitary plasmacytoma of bone (SPB), extramedullary plasmacytoma (EMP), multiple myeloma (MM) and plasma cell leukemia ${ }^{8}$. The organs involved in the SPB are mainly axial skeletal bones, such as vertebra and skull, while in EMP, the head and neck, nasal cavity and nasopharyngeal are commonly involved ${ }^{6}$. It has been reported that the rate of relapse after treatment for extramedullary plasmacytoma is $6-10 \%{ }^{9}$.

Also, MM is characterized by the proliferation of abnormal plasma cells and is usually limited to bone marrow ${ }^{10}$. Extramedullary plasmacytoma has been reported in $3 \%$ of patients with $\mathrm{MM}^{11}$. In these patients, orbital involvement is rare. According to the study performed by Burkat and colleagues ${ }^{12}$, from 1972 to 2009, 52 cases of orbital multiple myeloma with a mean age of 56.5 have been reported and in $81 \%$ of them, the most common symptom was proptosis. Based on our reviews, from 2010 to 2018, about 20 cases have been described, which are listed in Table 1 .

The mean age of these patients was 63.8 and in the many cases, orbital symptom has been unilateral (85\%). The proptosis and diplopia were the most abundant orbital clinical symptoms involved, while ptosis, retrobulbar lesion, and low vision were less common (Table 2). Also, systemic chemotherapy and radiotherapy are good therapeutic options that in the most reports, the positive response to treatment has been reported ${ }^{13}$. We reported a multiple myeloma patient with extramedullary plasmacytoma that was unique because of the unilateral retrobulbar lesion and its successful orbital surgery.

\section{CONCLUSION}

According to studies conducted to date, in patients with multiple myeloma, orbital symptoms often occur in adulthood and unilaterally. Additionally, the important point in these cases is that during differential diagnosis between the types of plasmacytomas, initially multiple myeloma should be considered.

\section{LIST OF ABBREVIATIONS}

BMA: bone marrow aspiration 
Table 1: Cases with orbital multiple myeloma from 2009-2018

\begin{tabular}{|c|c|c|c|c|c|c|c|}
\hline Author (yr) & $\begin{array}{c}\# \\
\text { Cases }\end{array}$ & $\begin{array}{l}\text { Age } \\
(\mathrm{yr})\end{array}$ & Sex & $\begin{array}{l}\text { Orbital } \\
\text { Symptoms }\end{array}$ & $\begin{array}{l}\text { Unilateral } \\
\quad v s . \\
\text { Bilateral }\end{array}$ & Typical management & Ref. \\
\hline $\begin{array}{l}\text { Burkat } \\
(2009)\end{array}$ & 1 & 65 & M & $\begin{array}{l}\text { decreased } \\
\text { vision and } \\
\text { eyelid pain }\end{array}$ & Unilateral & Orbital surgery and chemotherapy & 12 \\
\hline $\begin{array}{l}\text { Yumori } \\
(2010)\end{array}$ & 1 & 33 & M & $\begin{array}{l}\text { Vascularized } \\
\text { conjunctival } \\
\text { lesion }\end{array}$ & Bilateral & $\begin{array}{l}\text { Ophthalmic solution and } \\
\text { prednisolone acetate }\end{array}$ & 7 \\
\hline $\begin{array}{l}\text { Fernandez } \\
(2011)\end{array}$ & 1 & 53 & M & $\begin{array}{l}\text { Moderate ptosis } \\
\text { and hypotropia }\end{array}$ & Unilateral & $\begin{array}{l}\text { Chemotherapy treatment and } \\
\text { autologous bone marrow } \\
\text { transplantation }\end{array}$ & 14 \\
\hline Chin (2011) & 3 & $82,76,76$ & $\begin{array}{l}1 \mathrm{~F} \\
2 \mathrm{M}\end{array}$ & $\begin{array}{l}\text { Epibulbar } \\
\text { lesion and } \\
\text { proptosis }\end{array}$ & Unilateral & $\begin{array}{l}\text { Palliative radiotherapy and } \\
\text { chemotherapy } \\
\text { (melphalan and prednisone) }\end{array}$ & 15 \\
\hline Liao (2011) & 1 & 53 & $\mathrm{~F}$ & $\begin{array}{l}\text { Left globe } \\
\text { proptosis }\end{array}$ & Unilateral & Ocular surface lubrication & 16 \\
\hline Pan (2011) & 1 & 57 & $\mathrm{~F}$ & $\begin{array}{l}\text { Right eye } \\
\text { proptosis }\end{array}$ & Unilateral & $\begin{array}{l}\text { Pamidronate chemotherapy and } \\
\text { orbital radiotherapy }\end{array}$ & 17 \\
\hline $\begin{array}{l}\text { Terenzi } \\
(2012)\end{array}$ & 1 & 50 & M & $\begin{array}{l}\text { Retro-orbital } \\
\text { lesion }\end{array}$ & Unilateral & $\begin{array}{l}\text { Intensity-modulated radiotherapy } \\
\text { technique (IMRT) }\end{array}$ & 3 \\
\hline $\begin{array}{l}\text { Hassan } \\
(2012)\end{array}$ & 1 & 62 & $\mathrm{~F}$ & $\begin{array}{l}\text { Proptosis, } \\
\text { chemosis, } \\
\text { diplopia and } \\
\text { decreased } \\
\text { vision }\end{array}$ & Unilateral & Radiotherapy & 13 \\
\hline Felici (2013) & 1 & 73 & M & $\begin{array}{l}\text { Retro-orbital } \\
\text { localization }\end{array}$ & Bilateral & $\begin{array}{l}\text { Combination chemotherapy } \\
\text { (lenalidomide, } \\
\text { dexamethasone, and cyclophos- } \\
\text { phamide) }\end{array}$ & 18 \\
\hline $\begin{array}{l}\text { Varım } \\
(2015)\end{array}$ & 1 & 64 & M & $\begin{array}{l}\text { Peri-orbital } \\
\text { ecchymosis lesion } \\
\text { (raccoon eye) }\end{array}$ & Unilateral & $\begin{array}{l}\text { Combination chemotherapy (VAD } \\
\text { and VCD) }\end{array}$ & 19 \\
\hline $\begin{array}{l}\text { Galea } \\
(2015)\end{array}$ & 1 & 58 & $\mathrm{~F}$ & $\begin{array}{l}\text { Diplopia and } \\
\text { variable Ptosis }\end{array}$ & Bilateral & $\begin{array}{l}\text { Combination } \\
\text { chemotherapy (Cyclophosphamide } \\
\text {, Thalidomide, and } \\
\text { Dexamethasone) }\end{array}$ & 20 \\
\hline $\begin{array}{l}\text { Vatansever } \\
(2016)\end{array}$ & 1 & 68 & $\mathrm{~F}$ & $\begin{array}{l}\text { Right eye } \\
\text { proptosis }\end{array}$ & Unilateral & Palliative radiotherapy & 21 \\
\hline $\begin{array}{l}\text { Nambiar } \\
(2017)\end{array}$ & 1 & 63 & $\mathrm{~F}$ & $\begin{array}{l}\text { Ptosis and } \\
\text { diplopia }\end{array}$ & Unilateral & $\begin{array}{l}\text { Chemotherapy (bortezomib, } \\
\text { lenalidomide, and dexametha- } \\
\text { sone) }\end{array}$ & 22 \\
\hline $\begin{array}{l}\text { Wang } \\
(2018)\end{array}$ & 5 & $\begin{array}{l}68,73,51 \\
77 \\
75\end{array}$ & $\begin{array}{l}3 \mathrm{~F} \\
2 \mathrm{M}\end{array}$ & $\begin{array}{l}\text { The retrobulbar } \\
\text { lesion, diplopia, } \\
\text { and proptosis }\end{array}$ & Unilateral & $\begin{array}{l}\text { Orbital surgery in conjunction } \\
\text { with radiotherapy and } \\
\text { chemotherapy }\end{array}$ & 11 \\
\hline
\end{tabular}

M: male, F: female 


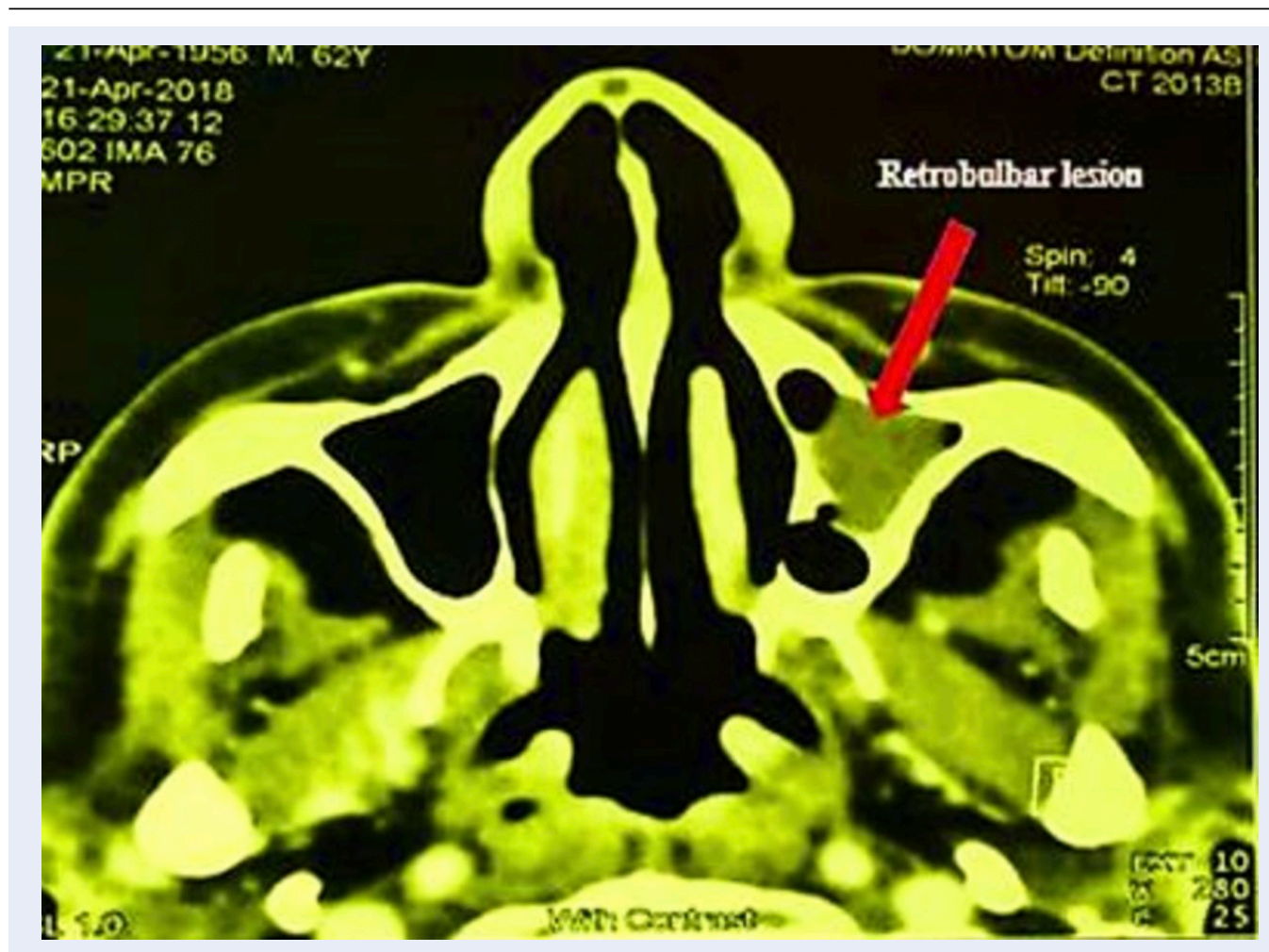

Figure 2: CT of the orbital showed a soft tissue mass in the retrobulbar.

Table 2: Characteristics of cases with orbital multiple myeloma

\begin{tabular}{ll} 
Characteristics & $\mathrm{N}: 20$ \\
Age & 63.8 \\
Sex & $10 \mathrm{M}(50 \%), 10 \mathrm{~F}(50 \%)$ \\
Unilateral & 3 Bil (15\%), 17 Uni (85\%) \\
vs. Bilateral & \\
Common orbital & Proptosis: $12(60 \%)$ \\
symptoms & Diplopia: $11(55 \%)$ \\
& Ptosis: $3(15 \%)$ \\
& Retro-bulbar (-orbital) lesion: $3(15 \%)$ \\
\hline
\end{tabular}

Bil: bilateral, Uni: unilateral

BUN: blood urea nitrogen

CBC: complete blood count

Cr: creatinine

CT: computed tomography

EMP: extramedullary plasmacytoma

FNAC: fine needle aspiration cytology

MM: multiple myeloma

RFT: renal function tests

SPB: solitary plasmacytoma of bone

VCD: velcade (bortezomib), cyclophosphamide, and dexamethasone

\section{ETHICS APPROVAL AND CONSENT TO PARTICIPATE}

Yes

\section{COMPETING INTERESTS}

The authors declare that they have no financial or other conflicts of interest.

\section{FUNDING}

None. 


\section{AUTHORS' CONTRIBUTIONS}

Mehrdad Payandeh \& Noorodin Karami: Literature search, Clinical studies, Data acquisition, Data analysis; Noorodin Karami: Manuscript preparation, Manuscript review, Guarantor; Afshin Karami: Concepts, Design, Definition of intellectual content, Literature search, Manuscript editing; Soode Enayati, Fatemeh Yari \& Mehrnoush Aeinfar: Manuscript editing, Literature search.

\section{REFERENCES}

1. Köhler M, Greil C, Hudecek M, Lonial S, Raje N, Wäsch R. Current developments in immunotherapy in the treatment of multiple myeloma. Cancer. 2018;124:2075-85. Available from: DOI:10.1002/cncr.31243.

2. Breen DP, Freeman CL, Silva RND, Derakhshani S, Stevens J. Soft tissue plasmacytomas in multiple myeloma. Lancet. 2017;390:2083. Available from: Doi:10.1016/s0140-6736(17) 31471-x.

3. Terenzi S, di Cristino D, Murgia A, Janniello D, Ponti E, Tolu B. Orbital Involvement in Multiple Myeloma: A Case Report. Journal of Cancer Therapy. 2012;3:1052-4. Available from: DOI:10.4236/jct.2012.36136.

4. Clamp JR. Some aspects of the first recorded case of multiple myeloma. Lancet. 1967;2:1354-6. Available from: Doi: 10.1016/s0140-6736(67)90935-x.

5. Weber DM. Solitary bone and extramedullary plasmacytoma. Hematology. 2005;2005:373-6. Available from: DOI:10.1182/ asheducation-2005.1.373.

6. Kilciksiz S, Karakoyun-Celik O, Agaoglu FY, Haydaroglu A. A review for solitary plasmacytoma of bone and extramedullary plasmacytoma. The Scientific World Journal. 2012;2012.

7. Yumori JW, llsen P, Bright DC. Conjunctival plasmacytoma. Optometry (St Louis, Mo). 2010;81:234-9. null. Available from: 10.1016/j.optm.2009.11.006.

8. Townend PJ, Kraus G, Coyle L, Nevell D, Engelsman A, Sidhu SB. Bilateral extramedullary adrenal plasmacytoma: case report and review of the literature. International Journal of Endocrine Oncology. 2017;4:67-73. Available from: DOI:10. 2217/ije-2016-0023.

9. Lim CC, Soong TK, Chuah KC, Subrayan V. Extramedullary plasmacytoma of the eyelid: a case report and review of literature. Clinical \& Experimental Optometry. 2013;96:349-51. Available from: DOI:10.1111/j.1444-0938.2012.00797.x.

10. Payandeh M, Karami N, Karami A, Aeinfar M, Yami A, Ghorbani S. A Good Therapeutic Strategy to Unrecognized HIV Infection in A Patient with Multiple Myeloma Undergoing Peripheral Blood Stem Cell Transplantation-Case Report. The Amer- ican Journal of Cancer. 2018;6:17-9

11. Wang SS, Lee MB, George A, Wang SB, Blackwell J, Moran S. Five cases of orbital extramedullary plasmacytoma: diagnosis and management of an aggressive malignancy. Orbit (Amsterdam, Netherlands). 2018;(7):1-8. Available from: 10.1080/01676830.2018.1490437.

12. Burkat CN, Buren JJV, Lucarelli MJ. Characteristics of orbital multiple myeloma: a case report and literature review. Survey of Ophthalmology. 2009;54:697-704. Available from: DOI:10. 1016/j.survophthal.2009.04.012.

13. Hassan M, Alirhayim Z, Sroujieh L, Hassan S. Multiple myeloma of the orbit. Case reports in ophthalmological medicine. 2012;2012.

14. Fernandez-Perez S, Satue M, Latorre RH, Mata GDL, Idoipe $M$, Garcia-Martin E. Orbital involvement in multiple myeloma. Acta Ophthalmologica. 2011;Special issue: Abstracts from the 2011 European Association for Vision and Eye Research Conference:89. Available from: 10.1111/j.1755-3768.2011.443.x.

15. Chin KJ, Kempin S, Milman T, Finger PT. Ocular manifestations of multiple myeloma: three cases and a review of the literature. Optometry (St Louis, Mo). 2011;82:224-30. Available from: DOI:10.1016/j.optm.2010.10.009.

16. Liao J, Greenberg A, Shinder R. Relapsed multiple myeloma presenting as an orbital plasmacytoma. Ophthalmic Plastic and Reconstructive Surgery. 2011;27:461. Available from: DOI:10.1097/IOP.0b013e31820d1c82.

17. Pan SW, Hitam WHW, Noor RAM, Bhavaraju VM. Recurrence of multiple myeloma with soft tissue plasmacytoma presenting as unilateral proptosis. Orbit (Amsterdam, Netherlands) 2011;30:105-7. Available from: Doi:10.3109/01676830.2010. 546553.

18. Felici $\mathrm{S}$, Villivà N, Balsamo $\mathrm{G}$, Andriani A. Efficacy of lenalidomide in association with cyclophosphamide and dexamethasone in multiple myeloma patient with bilateral retro-orbital localisation. ecancermedicalscience. 2013;7:331.

19. Varım C, Ergenc H, Uyanık MS, Kaya T, Nalbant A, Karacaer C. $A$ very rare presentation of multiple myeloma: unilateral rac coon eye. Open Access Macedonian Journal of Medical Sciences. 2015;3:436-8. Available from: 10.3889/oamjms.2015. 073.

20. Galea M, McMillan N, Weir C. Diplopia and variable ptosis as the sole initial findings in a case of orbital plasmacytoma and multiple myeloma. Seminars in ophthalmology. 2015;30:235237. Available from: 10.3109/13506129.2013.839807.

21. Vatansever M, Bozkurt FM, Dinç E, Yılmaz EB, Nayir E, Sarı AA. Orbital metastasis of multiple myeloma: case report. Turkish Journal of Ophthalmology. 2016;46:148-50. Available from: DOI: 10.4274/tjo.73645.

22. Nambiar RK, Nair SG, Mathew SP, Manohar AT. Ptosis and diplopia-sole manifestations in multiple myeloma. Annals of Blood. 2017;2:9. Available from: 10.21037/aob.2017.07.01.

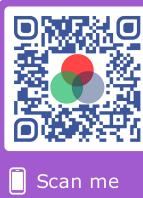

